\title{
Gaya Kepemimpinan Kepala Madrasah Dalam Meningkatkan Kompetensi Pedagogik Guru Di Madrasah Ibtidaiyah Kota Gorontalo
}

\author{
Marianti $^{1}$, Razak Umar ${ }^{2}$, Ruwiah A. Buhungo ${ }^{3}$ \\ ${ }^{123}$ IAIN Sultan Amai Gorontalo \\ email: mariasrii24@gmail.com
}

\begin{abstract}
Abstrak
Tujuan dalam penelitian ini adalah yaitu: Untuk mengetahui gaya kepemimpinan kepala madrasah di MI Al-Khairaat kota gorontalo provinsi gorontalo, mengetahui gaya kepemimpinan kepala madrasah dalam meningkatkan kompetensi pedagogik guru di mi al-khairaat kota gorontalo provinsi gorontalo, mengetahui upaya yang dilakukan kepala madrasah dalam meningkatkan kompetensi pedagogik guru di mi al-khairaat kota gorontalo provinsi gorontalo. Jenis penelitian yang digunakan adalah penelitian kualitatif deskriptif yaitu penelitian yang berusaha menyuguhkan dengan sistematis dan cermat fakta-fakta aktual dan sifat populasi tertentu. Teknik pengumpulan data digunakan metode observasi, wawancara dan dokumentasi. Teknik analisis yang digunakan yaitu reduksi data, Data Display dan penarikan kesimpulan. Hasil penelitian ini menunjukkan bahwa peneliti menarik kesimpulan yaitu: Gaya kepemimpinan Kepala Madrasah di MI Al-Khairaat Kota Gorontalo Provinsi Gorontalo bersifat demokratis, dan selalu menjunjung tinggi keputusan-keputusan yang di sepakati bersama. Sehingganya dalam meningkatkan kompetensi guru khususnya kompetensi pedagogik, karena Kemampuan kompetensi pedagogik merupakan salah satu kompetensi yang wajib dimiliki oleh setiap guru. Semakin baik kompetensi pedagogik guru yang dimiliki tersebut maka semakin baik pula kemampuannya dalam mengelolah pembelajaran. Dimana Kepala Madrasah selalu memotivasi guru, membuka peluang kepada seluruh guru untuk melanjutkan pendidikan dan pelatihan-pelatihan, seminar, dan workshop dengan terbaik dengan peningkatan kompetensi pedagogik guru. Dan menerapkan disiplin serta melakukan supervisi. Implikasi dari hasil penelitian ini bahwa gaya kepemimpinan kepala madrasah yang bersifat demokratis mampu meningkatkan kompetensi guru khususnya kompetensi pedagogik guru, baik dengan upaya pengelolaan dalam pembelajaran ataupun semacamnya, hanya saja dalam meningkatkan kompetensi pedagogik guru perlu adanya penekanan dari kepala madrasah dalam menerapkan kedisiplinan agar peningkatan dapat tercapai dengan baik.
\end{abstract}

Kata Kunci: Gaya Kepemimpinan Kepala Madrasah, Kompetensi Pedagogik

\section{PENDAHULAUAN}

Menjadi seorang kepala sekolah bukanlah perkara yang mudah, bukan pula perkara yang sulit, namun, ketika mengenal, memahami, menyakini cara menjadi kepala sekolah yang handal, maka hal yang niscaya melaksanakan tugas mulai menjadi seorang kepala sekolah akan terwujud dengan mudah. Oleh karena itu, mengenai kebutuhan 
penting untuk menjadi seorang kepala sekolah berdasar hasil penelitian dari kepemimpinan kepala sekolah. ${ }^{1}$

Kepemimpinan (leadership) tidak lain adalah kegiatan memimpin dengan proses mempengaruhi bawahan atau orang lain. Menurut Nawawi, ${ }^{2}$ menjelaskan bahwa kepemimpinan dapat diartikan sebagai kemampuan atau kecerdasan mendorong sejumlah orang (dua orang atau lebih) agar bekerja sama dalam melaksanakan kegiatan-kegiatan yang terarah pada tujuan bersama. Hal ini dipertegas dengan pendapat Robbins, yang mendefinisikan kepemimpinan sebagai kemampuan untuk mempengaruhi suatu kelompok dan mengarahkannya untuk mencapai tujuan tertentu.

seorang pendidik haruslah memiliki kemampuan sesuai dengan kompetensinya masing masing. Namun dalam kenyataan kompetensi yang dilaksanakan di madrasah sering guru mengajar tidak sesuai dengan disiplin ilmu pendidikannya. Kondisi ini sering terjadi di madrasah-madrasah dengan berbagai alasan diantaranya kurangnya mengikuti pelatihan-pelatihan, seminar worskhop maupun studi guru. Hal ini memicu adanya kemampuan mengelola pembelajaran peserta didik meliputi pemahaman terhadap peserta didik, perancangan dan pelaksanaan pembelajaran, evaluasi hasil belajar, dan pengembangan peserta didik untuk mengaktualisasikan berbagai potensi yang dimilikinya.

Berdasarkan hasil obvervasi pendahuluan dengan mewawancarai bapak Umar Tegila, M.Pd selaku Waka Kurikulum di Madrasah Ibtidaiyah Al-Khairaat Kota Gorontalo diperoleh keterangan bahwa dilakukan oleh peneliti, dimana kompetensi pada sebahagian guru belum sepenuhnya memenuhi standar sebagai pengajar, dan kebijakan kepala sekolah dalam meningkatkan kompetensi guru belum maksimal. Hal ini disebabkan oleh berbagai faktor diantaranya Madrasah Ibtidaiyah Al-Khairaat masih tergabung dalam ruang lingkup yayasan sehingga kebijakan juga dapat dipertimbangkan oleh pimpinan yayasan bahkan penentuan kebijakan tentang staf pengajar terkadang ditentukan oleh pihak yayasan.

Namun hal ini dapat diupayakan dengan kebijakan kepala sekolah untuk menunjang kompetensi guru. Kebijakan yang diambil oleh kepala sekolah dalam meningkatkan kompetensi guru diantaranya mewajibkan guru untuk mengikuti pendidikan dan pelatihan sesuai bidang masing masing. Selain itu kebijakan kepala sekolah sebagai pucuk pimpinan dalam madrasah menjadikan bahan ajar dan rencana pelakasanaan pembelajaran yang dibuat oleh guru berdasarkan kurikulum yang berlaku selalu dievaluasi serta pengadaan supervisi akademik bagi guru-guru yang mengajar. Berdasarkan uraian di atas, penulis dapat memformulasikan judul penelitian yakni "Implikasi Gaya Kepemimpinan Kepala Marasah Dalam Meningkatkan Kompetensi Pedagogik Guru di Madrasah Ibtidaiyah Al-Khairaat Kota Gorontalo Provinsi Gorontalo".

${ }^{1}$ Novianty Djafri, Manajemen Kepemimpinan Kepala Sekolah (Pengetahuan Manajemen, Efektivitas, Kemandirian Keunggulan Bersaing dan Kecerdasan Emosi, (Yogyakarta:Deepublish, 2017). h. 1 .

${ }_{2}^{2}$ Hadari Nawawi and M. Martini Hadari, Kepemimpinan yang Efektif, (Yogyakarta: Gajah Mada University Press, 2000). h. 9. 


\section{GAYA KEPEMIMPINAN}

Gaya (style) kepemimpinan ialah cara pemimpinan membawa diri sebagai pemimpin. Cara ini berlagak dan tampil dalam menggunakan kekuasaannya. Pemimpin ini mempunyai sifat, kebiasaan, temperamen, watak, dan kepribadian sendiri yang unik dan khas sehingga tingkah laku dan gayanya yang membedakan dirinya dengan orang lain. Gaya atau style hidupnya akan mewarnai perilaku dan tipe kepemimpinannya. ${ }^{3}$

Gaya kepemimpinan merupakan hasil interaksi antara pemimpin dan orang-orang yang dipimpinnya dalam berbagai keadaan yang mempengaruhinya. Gaya kepemimpinan yang menggambarkan perilaku dalam interaksi tersebut, bila dihimpun berdasarkan kesamaannya yang dominan, akan menghasilkan berbagai tipe kepemimpinan.

\section{KEPALA SEKOLAH}

Kepala sekolah adalah guru yang mendapat tugas tambahan sebagai kepala madrasah sekolah dimana peranannya sangat diperlukan dalam mengkoordinasikan, menggerakkan, dan menyerasikan semua sumber daya pendidikan yang tersedia di lembaganya. ${ }^{4}$ Kompleksnya tugas-tugas kepala sekolah bagaimana membuat lembaga itu berjalan dengan baik. Menciptakan keharmonisan di tengah-tengah anggotanya sehingga mampu mendorong kompetensi guru agar lebih baik dalam menjalankan profesinya. Kepala sekolah harus mampu memahami implikasi-implikasi dari perubahan sosial, ekonomi, Politik, dan educational : arti yang mereka sumbangkan kepada unit: untuk memulai dan memimpin perubahan-perubahan yang cocok di dalam unit di dasarkan atas perubahanperubahan sosial yang luas. ${ }^{5}$

Kepala sekolah sebagai pemimpin harus bertindak arif, bijaksana, dan adil, tidak ada pihak yang diancam dan dipaksa. Dengan kata lain, sebagai seorang pemimpin kepala sekolah harus dapat memperlakukan sama terhadap orang-orang yang menjadi bawahannya, sehingga tidak terjadi diskriminasi. Sehingga dapat diciptakan semangat kebersamaan diantara guru-guru, staf, para guru, staf suatu sekolah hendaknya selalu mendengarkan arahan, anjuran dari kepala sekolah sehingga saran tersebut selalu dapat memlihara bahkan meningkatkan semangat, rela berkorban, rasa kebersamaan dalam melaksanakan tugas-tugas masing-masing. Dalam mencapai tujuan setiap organisasi memerlukan dukungan, dana, sarana, dan sebagainya. Demikian pula sekolah sebagai suatu organisasi dalam rangka mencapai tujuan yang telah digariskan memerlukan berbagai dukungan. Kepala sekolah bertanggung jawab untuk memenuhi atau menyediakan dukungan yang diperlukann oleh para guru, staf, dan peserta didik, baik berupa dana, peralatan, waktu bahkan suasana yang mendukung. Tanpa adanya dukungan yang disediakan oleh kepala sekolah, sumber daya manusia yang tidak mungkin melaksanakan tugasnya dengan baik.

\footnotetext{
${ }^{3}$ Kartini Kartono, Pemimpin dan kepemimpinan, (Jakarta: Raja Grafindo persada, 2005), h. 34 .

4 Sidik, Firman. "KONSEP PENGEMBANGAN KURIKULUM PENDIDIKAN ISLAM." (2016): 100-114.

5 Danin Sudarwan, Inovasi Pendidikan dalam Upaya Peningkatan Profesionalisme Tenaga Kependidikan, ( Bandung: Pustaka Setia, 2002), h. 133.
} 
Kepala sekolah berperan sebagai katalisator, dalam arti mampu menimbulkan dan mengerakkan semangat para guru, staf, dan peserta didik dalam pencapaian tujuan yang telah ditetapkan. Patah semangat, kehilangan kepercayaaan harus dapat dibangkitkan kembali oleh kepala sekolah (catalysing). Sesuai dengan misi yang dibebankan kepala sekolah, kepala sekolah harus mampu membawa perubahan sikap, perilaku, intelektual peserta didik sesuai dengan tujuan pendidikan.

\section{KOMPETENSI PEDAGOGIK GURU}

Kompetensi pedagogik merupakan salah satu kompetensiyang harus dimiliki oleh guru sebagaimana tertuang dalam peraturan pemerintah, bahwa seorang guru dalam meningkatkan kualitasnya harus memiliki paling tidak empat kompetensi, yakni kompetensi pedagogik, kompetensi kepribadian, kompetensi sosial, dan kompetensi profesional. ${ }^{6}$ Kompetensi Pedagogik merupakan kemampuan yang berkaitan dengan pemahaman siswa dan pengelola pembelajaran yang mendidik dan dialogis. secara substansi, kompetensi ini mencakup kemampuan pemahaman terhadap peserta didik, perencanaan dan pelaksanaan pembelajaran, evaluasi hasil belajar, dan pengembangan siswa untuk mengaktualisasikan berbagai potensi yang dimilikinya. ${ }^{7}$ Secara pedagogik, kompetensi guru-guru dalam mengelola pembelajaran perlu mendapat perhatian yang serius. Hal ini penting, karena pendidikan di Indonesia dinyatakan kurang berhasil oleh sebagian masyarakat, dinilai dari aspek pedagogik dan sekolah nampak lebih mekanis sehingga peserta didik cenderung kerdil karena tidak mempunyai dunianya sendiri. Freire mengkritisi kondisi pendidikan seperti ini sebagai penjajahan dan penindasan, yang harus diubah menjadi pemberdayaan dan pembebasan. Freire juga mengungkapkan bahwa proses pembelajaran, yakni hubungan guru dan peserta didik disemua tingkatan identik dengan watak bercerita. ${ }^{8}$ Sedangkan menurut Undang-undang Sistem Pendidikan Nasional No.20 tahun 2003 menyatakan bahwa: "pembelajaran adalah proses interaksi peserta didik dengan sumber belajar pada suatu lingkungan belajar. ${ }^{9}$

\section{METODE}

Metode penelitian yang di gunakan dalam penelitian ini adalah metode penelitian kualitatif, penelitian kualitatif sebagaimana pendapat Ulin Biki dengan pengutip pendapat Bogdan dan Taylor adalah prosedur penelitian yang menghasilkan data deskriptif berupa kata-kata tertulis atau lisan dari orang-orang dan perilaku yang diamati. Jadi dengan demikian dalam penelitian kualitatif lebih menonjolkan pada upaya pengolahan dan dalam kata-kata bukan dalam angka-angka sebagaimana dalam penelitian kualitatif.

${ }^{6}$ Sidik, Firman. "Guru Berkualitas Untuk Sumber Daya Manusia Berkualitas." Tadbir: Jurnal Manajemen Pendidikan Islam 4.2 (2016): 109-114.

7 Jamil Suprihatininggrum, Guru Profesional: Pedoman Kinerja, Kualifikasi dan Kompetensi Guru, (Cet. 3; Jogjakarta: Ar-Ruzz Media, 2016), h. 101.

${ }^{8}$ E. Mulyasa, Standar Kompetensi dan Sertifikasi Guru, (Bandung: Rosdakarya, 2008) h.

${ }^{9}$ Erwinsyah, Alfian. "Manajemen Pembelajaran Dalam Kaitannya Dengan Peningkatan Kualitas Guru." Tadbir: Jurnal Manajemen Pendidikan Islam 5.1 (2017): 69-84. 
Metode kualitatif ini di gunakan oleh peneliti karena data yang telah terkumpul baik memalui observasi, wawancara, dan dokumen-dokumen kemudian digambarkan dalam bentuk kata-kata dengan terlebih dahulu menganalisis secara tajam terhadap data yang telah terkumpul. Jenis penelitian yang di gunakan adalah penelitian studi kasus, yakni suatu bentuk penelitian yang berusaha memberikan gambaran secara sistematis dan cermat melalui fakta-fakta yang di teliti. Penelitian studi kasus adalah jenis penelitian yang memberikan gambaran atau uraian atas suatu keadaan sejernih tanpa ada perlakuan khusus terhadap objek yang di teliti. ${ }^{10}$

Jenis penelitian kualitatif / non statistik dengan metode deskriptif memiliki penelitian yang terbatas pada usaha mengungkapkan suatu masalah dan keadaan sebagaimana adanya, sehingga hanya merupakan penyikapan fakta, mencari informasi tentang keadaan secara nyata atau suatu gambaran yang jelas dan akurat tentang fenomena yang sedang di teliti.

\section{HASIL PENELITIAN}

Gaya kepemimpinan di madrasah ini masih agak kesulitan menentukan, karena kepala madrasah yang sekarang masih baru menjabat dalam beberapa bulan ini, akan tetapi tidak menutup kemungkinan dalam masa jabatan beliau memiliki gaya kepemimpinan berbagai macam diantaranya demokratis, paternalistik, atau pengutamakan kebersamaan seperti bermusyawarah dan terkadang kami juga melihatnya sebagai pemimpin yang otoriter atau otokratik, bahkan bisa dikatakan ada perpaduan antara berbagai tipe kepemimpinan. Sehingga kalau saya melihat secara umum saya masih melihatnya dari sisi mana pola itu kita lihat, misalnya pada masalah tertentu demokratis betul pada masalah tertentu juga bisa otoriter karena hal tersebut kepala madrasah sangat karismatik serta selalu menyandarkan pada hal-hal yang menjadi dasar kasus atau kebijakan apa yang diambil dan dengan cara seperti apa. Karena ada kebijakan langsung dari kepala madrasah, ada yang dimusyawarahkan dan ada juga yang diserahkan langsung kepada waka-wakanya.

Gaya kepemimpinan Kepala Madrasah di MI Al-Khairaat Kota Gorontalo Provinsi Gorontalo bersifat demokratis, dan selalu menjunjung tinggi keputusankeputusan yang di sepakati bersama. Sehingganya dalam meningkatkan kompetensi guru khususnya kompetensi pedagogik, karena Kemampuan kompetensi pedagogik merupakan salah satu kompetensi yang wajib dimiliki oleh setiap guru. Semakin baik kompetensi pedagogik guru yang dimiliki tersebut maka semakin baik pula kemammpuannya dalam mengelolah pembelajaran. Upaya Kepala Madrasah MI Al-Khairaat Kota Gorontalo Provinsi Gorontalo dalam meningkatkan kompetensi pedagogik guru adalah Kepala Madrasah selalu memotivasi guru, membuka peluang kepada seluruh guru untuk melanjutkan pendidikan dan pelatihan-pelatihan, seminar, dan workshop dengan terbaik dengan peningkatan kompetensi pedagogik guru. Dan menerapkan disiplin serta melakukan supervisi.

${ }^{10}$ Kountur Ronny, Metode Penelitian Untuk Penulisan Skripsi Dan Tesis, (Jakarta: PPM, 2004), h. 53 


\section{DAFTAR PUSTAKA}

Djafri, Novianty. Manajemen Kepemimpinan Kepala Sekolah (Pengetahuan Manajemen, Efektivitas, Kemandirian Keunggulan Bersaing dan Kecerdasan Emosi. Yogyakarta: Deepublish. 2017.

E. Mulyasa. Standar Kompetensi dan Sertifikasi Guru. Bandung: Rosdakarya. 2008.

Jamil Suprihatininggrum. Guru Profesional: Pedoman Kinerja, Kualifikasi dan Kompetensi Guru. Cet. 3; Jogjakarta: Ar-Ruzz Media. 2016.

Erwinsyah, Alfian. "Manajemen Pembelajaran Dalam Kaitannya Dengan Peningkatan Kualitas Guru." Tadbir: Jurnal Manajemen Pendidikan Islam 5.1 (2017): 69-84.

Kartono, Kartini. Pemimpin dan kepemimpinan. Jakarta: Raja Grafindo persada. 2005. h. 34.

Nawawi, Hadari and M. Martini Hadari. Kepemimpinan yang Efektif. Yogyakarta: Gajah Mada University Press. 2000.

Ronny, Kountur. Metode Penelitian Untuk Penulisan Skripsi Dan Tesis. Jakarta: PPM. 2004.

Sidik, Firman. "KONSEP PENGEMBANGAN KURIKULUM PENDIDIKAN ISLAM." (2016): 100-114.

Sidik, Firman. "Guru Berkualitas Untuk Sumber Daya Manusia Berkualitas." Tadbir: Jurnal Manajemen Pendidikan Islam 4.2 (2016): 109-114.

Sudarwan, Danin. Inovasi Pendidikan dalam Upaya Peningkatan Profesionalisme Tenaga Kependidikan. Bandung: Pustaka Setia. 2002. 